\title{
Human immunodeficiency virus and female prostitutes, Sydney 1985
}

\author{
C R PHILPOT, C HARCOURT, J EDWARDS, A GREALIS \\ From the Sydney STD Centre, Sydney Hospital, New South Wales, Australia
}

SUMMARY One hundred and thirty two female prostitutes and 55 non-prostitutes who were tested for antibodies to human immunodeficiency virus (HIV) were surveyed by questionnaire at this centre. The two groups were well matched for age and were very similar in other respects, except for numbers of their sexual partners. Questions were asked about drug taking, sexual practices, general health, and episodes of sexually transmitted diseases (STDs).

None of the women in the survey was found to be seropositive, but both groups were found to be seriously at risk of HIV infection through using intravenous (IV) drugs, having unprotected sexual intercourse with men who used IV drugs, having unprotected sexual intercourse with bisexual men, or exposure to several STDs.

The published results of testing for antibodies to human immunodeficiency virus (HIV) in female prostitutes have shown considerable variation in the prevalence of infection in different populations.

A survey of prostitutes in seven geographical areas of the USA showed that the seroprevalence of HIV antibodies paralleled the incidence in other women living in the same areas, and ranged from $0 \%$ to $57 \%$. $^{\prime}$ In Europe, prostitutes in London, Paris, and Nuremburg were antibody negative. ${ }^{12}$ Other studies in Athens, ${ }^{3}$ Pordenone (Italy), Zurich, and six West German cities, however, showed that $1 \%$ to $78 \%$ of the women tested were antibody positive. ${ }^{1}$ The influence of sexual exposure alone was not known, however, as in studies that detected antibody positive women an appreciable proportion of the affected prostitutes were IV drug users. The only exception was the Athens study, which reported no IV drug usage among the 12 seropositive women in a cohort of 200 registered prostitutes. A very high prevalence of HIV antibodies was found in some prostitutes in Rwanda $(88 \%)^{4}$ and Kenya $(66 \%$ of the lower socio-economic group), ${ }^{5}$ which suggested that in those African countries prostitutes played an important part in the sexual transmission of the disease. In Asia the presence of HIV antibodies in prostitutes has been reported from India, ${ }^{6}$ and the Philippines (BM Whyte, personal communication), ${ }^{7}$ but a large survey in Thailand in

Address for reprints: Dr C R Philpot, Sydney STD Centre, Nightingale Wing, Sydney Hospital, Macquarie Street, Sydney, New South Wales 2000, Australia

Accepted for publication 21 September 1987
1985 detected antibodies in none of 2880 female prostitutes.?

We report here a study, undertaken in Sydney, of a group of women working as prostitutes and a comparison group of non-prostitute women. Both groups were drawn from patients attending this centre, which has the largest female STD clinic in New South Wales. Our aim was to assess the exposure to HIV, as assessed by serology, in a well defined cohort of prostitutes in Sydney and to elucidate the risk factors for infection.

\section{Patients and methods}

From January to September 1985 we enrolled in the study 132 female prostitutes and 55 women with no history of prostitution. The only criteria for enrolment were that the women were patients at this centre and had voluntarily been tested for HIV antibodies. Confidentiality was guaranteed by the use of a code, which was different from the clinic number routinely assigned to each patient at the STD Centre, and no names were used in the survey.

We collected information on a wide range of social and medical factors by a questionnaire, which was largely self administered unless language problems necessitated administration by an interviewer. Medical histories and personal details gained through the questionnaire were subsequently checked against clinic records and, when necessary, the information given was corrected or supplemented. Responses to the self-administered questions were validated by the subsequent use of an expanded version of the questionnaire in interviews. 
As far as possible, given the limitations of a busy clinic, every woman who sought an HIV antibody test was asked to take part in the survey. Both groups were recruited in the same way by counsellors and nurses when they received information about the procedures for HIV antibody testing. We distributed 302 questionnaires to consecutive patients, and 190 were handed back to the staff for analysis. Three prostitutes returned incomplete questionnaires and were excluded from the study. The remaining 132 prostitutes represented $34 \%$ of the total number (387) of female prostitutes who attended the centre and were tested for HIV antibodies in 1985. None was found to have positive results at that time.

Comparison with routine statistics collected by the centre indicated that both groups represented a reasonable cross section of the female clinic population in 1985 , even though they were not necessarily representative of the female or the female prostitute population in the city as a whole. These women were among the first people in Australia to request HIV antibody testing, and therefore presumably indentified themselves as being particularly at risk.

\section{LABORATORY ANALYSIS}

We collected $10 \mathrm{ml}$ of blood from each woman and sent it to the Centre for Immunology, St Vincent's Hospital, Darlinghurst. Serum was tested for antibodies to HIV by an enzyme linked immunosorbent assay (ELISA) (Electronucleonics, Columbia, Maryland, USA ${ }^{8}$ and confirmed by the $\mathrm{H} 9$ exclusionary ELISA and by immunofluorescence using a $T$ cell line infected with HIV. ${ }^{910}$

\section{Results}

\section{HIV ANTIBODY TEST RESULTS}

All 132 prostitutes and 55 non-prostitutes were seronegative for antibodies to HIV.

AGE

Table 1 shows that the two groups were similar in their ages, the prostitutes having a slightly lower median age

Table 1 Ages of 187 women tested for antibody to human immunodeficiency virus

\begin{tabular}{lll}
\hline Age (years) & $\begin{array}{l}\text { No (\%) of } \\
\text { prostitutes } \\
(n=132)\end{array}$ & $\begin{array}{l}\text { No (\%) of } \\
\text { non-prostitutes } \\
(n=55)\end{array}$ \\
\hline$<20$ & $11(8)$ & $3(6)$ \\
$20-24$ & $30(23)$ & $9(16)$ \\
$25-29$ & $44(33)$ & $20(36)$ \\
$30-34$ & $25(19)$ & $11(20)$ \\
$35-39$ & $15(11)$ & $7(13)$ \\
$40-44$ & $2(2)$ & $2(4)$ \\
$45-49$ & $2(2)$ & $3(6)$ \\
$>49$ & $3(2)$ & 0 \\
\hline
\end{tabular}

Table 2 Drug use in 187 women tested for antibody to human immunodeficiency virus

\begin{tabular}{lll}
\hline Drug use & $\begin{array}{l}\text { No }(\%) \text { of } \\
\text { prostitutes } \\
(n=132)\end{array}$ & $\begin{array}{l}\text { No }(\%) \text { of } \\
\text { non-prostitutes } \\
(n=55)\end{array}$ \\
\hline Intravenous drugs ever & $25(19)$ & $13(24)$ \\
In previous six months: & $14(11)$ & $7(13)$ \\
Heroin & $5(4)$ & $1(2)$ \\
Barbiturates & $22(17)$ & $9(16)$ \\
Tranquillisers & $7(5)$ & $3(5)$ \\
Antidepressants & $8(6)$ & $10(18)$ \\
Amphetamines & $6(5)$ & $1(2)$ \\
Amyl nitrite & $52(39)$ & $24(44)$ \\
Marihuana & $18(14)$ & $6(11)$ \\
Cocaine & $49(37)$ & $25(46)$ \\
None of the above & $10(8)$ & $1(2)$ \\
No information & & \\
\hline
\end{tabular}

(27.5 years) than the non-prostitutes (28.25 years). Most women (69 $(52 \%)$ prostitutes, 31 (56\%) nonprostitutes) were aged 25 to 35 .

\section{DRUG USE}

Table 2 shows that the two groups were also similar in their drug using behaviour, although the comparison here may be skewed by the fact that more prostitutes $(10(8 \%) v$ one $(2 \%)$ non-prostitute) either did not answer the question about drug use or gave ambiguous answers that could not be coded.

Twenty five $(19 \%)$ prostitutes and $13(24 \%)$ nonprostitutes had used IV drugs at some time, and 14 $(11 \%)$ prostitutes and seven $(13 \%)$ non-prostitutes had used heroin in the previous six months. More prostitutes $(18,14 \%)$, than non-prostitutes (six, $11 \%)$ had used cocaine, but the pattern was reversed for marihuana, which had been used by $52(39 \%)$ prostitutes, as opposed to $25(44 \%)$ non-prostitutes. Small numbers of both groups had used barbiturates (five $(4 \%)$ and one (2\%) respectively) and amyl nitrite (six $(5 \%)$ and one (2\%) respectively). Substantially more non-prostitutes, however, used amphetamines (10 (18\%) compared with eight (6\%) prostitutes). Forty nine $(37 \%)$ prostitutes and $25(45 \%)$ non-prostitutes said that they had not used any of the named drugs during the preceding six months.

Table 3 Number of sexual partners in preceding month of 187 women tested for antibody to human immunodeficiency virus

\begin{tabular}{lll}
\hline $\begin{array}{l}\text { No of sexual } \\
\text { partners }\end{array}$ & $\begin{array}{l}\text { No }(\%) \text { of } \\
\text { prostitutes } \\
(n=132)\end{array}$ & $\begin{array}{l}\text { No }(\%) \text { of } \\
\text { non-prostitutes } \\
(n=55)\end{array}$ \\
\hline 0 & 0 & $10(18)$ \\
1 & $11(8)$ & $25(46)$ \\
$2-5$ & $8(6)$ & $13(24)$ \\
$6-20$ & $19(14)$ & 0 \\
$21-50$ & $16(12)$ & 0 \\
$51-100$ & $13(10)$ & 0 \\
$>100$ & $15(11)$ & 0 \\
No information & $61(46)$ & $3(6)$ \\
\hline
\end{tabular}


Table 4 Risk taking behaviour of sexual partners of 187 women tested for antibody to human immunodeficiency virus

\begin{tabular}{lll}
\hline $\begin{array}{l}\text { One or more partners in } \\
\text { the following risk groups } \\
\text { in previous five years }\end{array}$ & $\begin{array}{l}\text { No (\%) of } \\
\text { prostitutes } \\
(n=132)\end{array}$ & $\begin{array}{l}\text { No (\%) of } \\
\text { non-prostitutes } \\
(n=55)\end{array}$ \\
\hline Bisexual man & $45(34)$ & $22(40)$ \\
(Not sure) & $13(10)$ & $1(2)$ \\
Homosexual man & $14(11)$ & $1(2)$ \\
(Not sure) & $3(2)$ & 0 \\
Male prostitute & $17(13)$ & $4(7)$ \\
(Not sure) & $4(3)$ & 0 \\
Intravenous drug user & $38(29)$ & $18(33)$ \\
(Not sure) & $10(8)$ & 0 \\
\hline
\end{tabular}

\section{SEXUAL CONTACTS}

Table 3 shows the number of sexual partners reported by the women in the month before completing the questionnaire. The ranges (medians) were 1 to 250 (24.5) for prostitutes and 0 to $4(1.5)$ for nonprostitutes. Over a one year period the corresponding figures were: 1 to 3000 (median 175) for prostitutes and 1 to 13 (median 3.5) for non-prostitutes. Only 70 $(53 \%)$ of prostitutes answered this question, however, which may have been for several reasons. Firstly, there are real difficulties in calculating the number of clients in any period, because of the changeable work conditions and irregular working days of most prostitutes. Secondly, many prostitutes are reluctant to give any information that might indicate how much they are earning. Thirdly, several prostitutes apparently misinterpreted the question as asking how many nonpaying sexual partners - that is, lovers-they had. In the careful distinction prostitutes make between their working and their private lives, "partner" generally refers to lovers whereas paying sexual partners are almost always referred to as clients, and this word did not appear in the question. As an interesting exercise we tried discounting those prostitutes who claimed that they had fewer than 10 sexual partners in the last year (on the assumption that they had only counted their lovers). On this basis the median number of sexual contacts a year rose from 175 to 450 . The corresponding figures a month rose from $24 \cdot 5$ to $40 \cdot 25$.

Table 4 shows that a surprisingly high proportion (over one third) of both groups recorded that they had had bisexual partners during the previous five years. A further $13(10 \%)$ prostitutes said they suspected that some of their partners were bisexual, but could not be sure. Many (38 $(29 \%)$ prostitutes, $18(33 \%)$ nonprostitutes) also recorded partners at risk from IV drug usage and from being male prostitutes $(17$ (13\%) prostitutes, four (7\%) non-prostitutes).

\section{SEXUALLY TRANSMITTED DISEASES (STDs)}

Table 5 shows the number of women affected, and the numbers of episodes of STDs that they had experienced during the previous five years. Analysis using Student's $t$ test shows that this cohort of prostitutes had significantly more episodes of gonorrhoea, chlamydial infection, and pelvic inflammatory disease (PID) than the non-prostitute cohort $(p<0.05)$. They also reported more genital warts and abnormal Papanicolaou smears, but these differences were not significant.

In addition to the conditions shown in the table, seven women (six prostitutes and one non-prostitute) had contracted molluscum contagiosum, one prostitute had been infested with Entamoeba histolytica,

Table 5 Sexually transmitted diseases (STDs) of 132 prostitutes and 55 non-prostitutes in previous five years

\begin{tabular}{|c|c|c|c|c|c|c|c|}
\hline \multirow[b]{2}{*}{$S T D$} & \multirow[b]{2}{*}{ Group } & \multicolumn{5}{|c|}{ No (\%) who had following No of episodes: } & \multirow[b]{2}{*}{ Total } \\
\hline & & 1 & 2 & 3 & 4 & $5+$ & \\
\hline $\begin{array}{l}\text { Gonorrhoea } \\
\text { Chlamydial infection } \\
\text { Pelvic inflammatory disease } \\
\text { Syphilis } \\
\text { Hepatitis A } \\
\text { Hepatitis B } \\
\text { Herpes } \\
\text { Trichomoniasis } \\
\text { Thrush } \\
\text { Genital or anal warts } \\
\text { Abnormal Papanicolaou smear }\end{array}$ & $\begin{array}{l}\text { Prostitutes } \\
\text { Non-prostitutes } \\
\text { Prostitutes } \\
\text { Non-prostitutes } \\
\text { Prostitutes } \\
\text { Non-prostitutes } \\
\text { Prostitutes } \\
\text { Non-prostitutes } \\
\text { Prostitutes } \\
\text { Non-prostitutes } \\
\text { Prostitutes } \\
\text { Non-prostitutes } \\
\text { Prostitutes } \\
\text { Non-prostitutes } \\
\text { Prostitutes } \\
\text { Non-prostitutes } \\
\text { Prostitutes } \\
\text { Non-prostitutes } \\
\text { Prostitutes } \\
\text { Non-prostitutes } \\
\text { Prostitutes } \\
\text { Non-prostitutes }\end{array}$ & $\begin{array}{r}36(28) \\
6(11) \\
37(28) \\
10(18) \\
19(14) \\
4(7) \\
3(2) \\
1(2) \\
4(3) \\
1(2) \\
8(6) \\
4(7) \\
31(24) \\
11(20) \\
36(27) \\
13(24) \\
41(31) \\
17(31) \\
25(19) \\
9(16) \\
17(13) \\
4(7)\end{array}$ & $\begin{array}{c}23(17) \\
1(2) \\
11(8) \\
2(4) \\
6(5) \\
1(2) \\
0 \\
0 \\
0 \\
0 \\
0 \\
1(2) \\
8(6) \\
0 \\
10(8) \\
1(2) \\
16(12) \\
4(7) \\
4(3) \\
0 \\
4(3) \\
1(2)\end{array}$ & $\begin{array}{l}9(7) \\
0 \\
7(5) \\
0 \\
1(1) \\
0 \\
0 \\
0 \\
0 \\
0 \\
0 \\
0 \\
8(6) \\
3(6) \\
5(4) \\
1(2) \\
12(9) \\
1(2) \\
4(3) \\
0 \\
0 \\
0\end{array}$ & $\begin{array}{l}6(5) \\
0 \\
1(1) \\
0 \\
1(1) \\
0 \\
0 \\
0 \\
0 \\
0 \\
0 \\
0 \\
3(2) \\
2(4) \\
4(3) \\
1(2) \\
2(2) \\
1(2) \\
0 \\
0 \\
0 \\
0\end{array}$ & $\begin{array}{l}2(2) \\
0 \\
5(4) \\
0 \\
2(2) \\
0 \\
0 \\
0 \\
0 \\
0 \\
0 \\
0 \\
17(13) \\
5(9) \\
13(10) \\
1(2) \\
13(10) \\
3(6) \\
0 \\
0 \\
0 \\
0\end{array}$ & $\begin{array}{c}76(58) \\
7(13) \\
61(46) \\
12(22) \\
29(22) \\
5(9) \\
3(2) \\
1(2) \\
4(3) \\
1(2) \\
8(6) \\
5(9) \\
67(51) \\
21(38) \\
68(52) \\
17(31) \\
84(64) \\
26(47) \\
33(25) \\
9(16) \\
21(16) \\
5(9)\end{array}$ \\
\hline
\end{tabular}


Table 6 Use of condoms by sexual partners of 187 women tested for antibody to human immunodeficiency virus

\begin{tabular}{lll}
\hline $\begin{array}{l}\text { \% Partners } \\
\text { using condoms }\end{array}$ & $\begin{array}{l}\text { No (\%) of } \\
\text { prostitutes } \\
(n=132)\end{array}$ & $\begin{array}{l}\text { No (\%) of } \\
\text { non-prostitutes } \\
(n=55)\end{array}$ \\
\hline 0 & $16(12)$ & $42(76)$ \\
$1-10$ & $40(30)$ & $5(9)$ \\
$11-20$ & $9(7)$ & $1(2)$ \\
$21-40$ & $15(11)$ & $1(2)$ \\
$41-60$ & $13(10)$ & $2(4)$ \\
$61-80$ & $5(4)$ & 0 \\
$81-99$ & $11(8)$ & 0 \\
100 & $14(11)$ & $3(6)$ \\
No information & $9(7)$ & $1(2)$ \\
\hline
\end{tabular}

two prostitutes had been diagnosed as having chronic PID, and one non-prostitute had been treated for cancer of the cervix. Of the eight episodes of hepatitis $B$ in prostitutes, four occurred in IV drug users and four in non-IV drug users. One non-IV drug user was a confirmed carrier of hepatitis B virus, and one IV drug user claimed to have had hepatitis B twice and hepatitis A once in the previous five years, though this could not be substantiated from her clinic records.

Seven $(5 \%)$ prostitutes and six $(11 \%)$ nonprostitutes had contracted no STD in the previous five years, and we had no information for three $(2 \%)$ prostitutes.

\section{USE OF CONDOMS}

Table 6 shows the numbers of women whose sexual partners used condoms and for what percentage of sexual encounters. The numbers who used condoms regularly were very low in both groups. Condoms were not used at all by the partners of $42(76 \%)$ nonprostitutes, and the partners of $65(49 \%)$ prostitutes used condoms in fewer than $20 \%$ of encounters. Only the partners of $14(11 \%)$ prostitutes used condoms all the time.

\section{Discussion}

This study was performed when HIV antibody testing had just become available in New South Wales, and there was a high level of publicly expressed concern about the possibility of the rapid spread of the acquired immune deficiency syndrome (AIDS) to heterosexual men and women via prostitution. None of the total of 387 prostitutes who were tested in the Sydney STD Centre during 1985, however, was seropositive. Nevertheless the cohort of 132 prostitutes and 55 non-prostitutes who completed our questionnaire clearly could have been exposed to the virus in several ways.

The risk factors most commonly associated with the spread of the virus in the West are some homosexual and bisexual practices and the sharing of syringes and needles in the use of IV drugs. In 1985, before the widespread introduction of improved blood testing procedures, recipients of blood and blood products were also at risk. Concomitant STDs have also been directly associated with HIV antibody positivity in African heterosexual women" and in European homosexual men. ${ }^{1213}$

A high proportion of the women in our study were at risk of infection because of the behaviour of their sexual partners. Many women in each group reported sexual contacts with partners who were bisexual, used IV drugs, or were male prostitutes. Heterosexual transmission of HIV from men in high risk groups has been well documented ${ }^{14-16}$ and there is epidemiological evidence of female to male sexual transmission. ${ }^{17}$ In Africa the evidence suggests that AIDS is spread predominantly through heterosexual activity. ${ }^{1819}$

In addition to having high risk partners, several women in the study put themselves directly at risk through their own behaviour; $19 \%$ of prostitutes and $24 \%$ of non-prostitutes gave histories of IV drug use. HIV antibodies have been reported in IV drug users in Sydney, ${ }^{20}$ and IV drug use has been found to be associated with HIV infection in female prostitutes and in non-prostitute women. ${ }^{121}$ Apart from intravenous drugs many women swallowed or inhaled large quantities of other drugs. Tranquillisers, marihuana, heroin, and cocaine were each used by $10 \%$ or more of both groups. The figures on drug usage indicate that a large number of women in this survey led unhealthy and stressful lives that may well have lowered their resistance to infection.

STD histories showed that a similar range of diseases was experienced by both groups of women. The higher incidence of some STDs in prostitutes is probably attributable to the very high numbers of sexual partners that they encounter. In other studies specific STDs have been associated with seroconversion or the progression of HIV infection, or both. They include gonorrhoea, ${ }^{451218}$ syphilis, ${ }^{1322}$ and hepatitis. ${ }^{12} 1322 \mathrm{~A}$ study in 1986 described a significant association between a lifetime number of episodes of STDs and seroconversion. ${ }^{12}$ It also showed that a history of an acute infection with STD during the year before examination was associated with the development of HIV antibody, or the progression of HIV infection.

The risk of the sexual transmission of HIV and the spread of other STDs may be considerably reduced by the widespread use of condoms. ${ }^{2324}$ In this study, however, condom usage by women in both groups was low. Only $14(11 \%)$ prostitutes and three $(5 \%)$ nonprostitutes used condoms for every sexual encounter. Conversely, $65(49 \%)$ prostitutes and $48(87 \%)$ nonprostitutes used condoms in only one in five encounters, or fewer. Given the previously described large numbers of partners engaging in "risky" behaviour, 
this level of unprotected sexual activity adds greatly to the potential for spread of HIV infection.

The absence of any HIV antibody positivity in this cohort of risk taking women might be explained by the small number of antibody positive people in the heterosexual population in Australia at that time, ${ }^{21}$ and the fact that the women tested were self selected patients attending the STD Centre. The prostitutes were not fully representative of the Sydney prostitute population as a whole, and in particular did not include women who worked predominantly on the street, from single rooms, or in small brothels in the inner city. Most of them were parlour prostitutes who underwent regular health checks.

Notwithstanding the absence of any detectable level of HIV infection in female prostitutes in Sydney in 1985 , we conclude that the virus could spread rapidly within the prostitution industry and back into the wider community through sexual contacts and IV drug use. There is therefore an urgent need to enhance current control measures including: the preventive education of the women themselves, their sexual partners, clients and the managers of prostitution premises; the continued provision of condoms and of safer sex information; and initiatives to reduce the practice of intravenous needle sharing by prostitutes who use drugs. It is also essential to continue to monitor the health of prostitutes during this early stage of the heterosexual spread of HIV infection in Australia.

A larger, long term, prospective study of HIV seroprevalance in prostitutes, based on this work, is in progress.

We thank Mr Brett Tindall (Centre for Immunology, St Vincents Hospital, New South Wales) for his help with recording and analysing the statistical data. The study was supported in part by a grant from the New South Wales Department of Health.

\section{References}

1 Centers for Disease Control. Antibody to human immunodeficiency virus in female prostitutes. MMWR 1987;36:157-61.

2 Smith GL, Smith KF. Lack of HIV infection and condom use in licensed prostitutes. Lancet 1986;ii:1392.

3 Papaevangelou G, Roumeliotou-Karayannis A, Kallinikos G, Papoutsakis G. LAV/HTLV-III infection in female prostitutes. Lancet 1985;ii:1018.

4 Van de Perre P, Carael M, Robert-Guroff M, et al. Female prostitutes: a risk group for infection with human T-cell lymphotropic virus type III. Lancet 1985;ii:524-7.

5 Kreiss JK, Koech D, Plummer FA, et al. AIDS virus infection in
Nairobi prostitutes: spread of the epidemic to East Africa. $N$ Engl J Med 1986;314:414-8.

6 John TJ, Babu PG, Jayakumari H, Simoes EAF. Prevalence of HIV infection in risk groups in Tamilnadu, India. Lancet 1987;i:160-1.

7 Traisupa A, Wongba C, Taylor DN. AIDS and prevalence of antibody to human immunodeficiency virus (HIV) in high risk groups in Thailand. Genitourin Med 1987;63:106-8.

8 Sarngadharan MG, Popovic M, Bruch L, Schupbach J, Gallo RC. Antibodies reactive with human T-lymphotropic retroviruses (HTLV-III) in the serum of patients with AIDS. Science 1984;224:506-8.

9 Levy JA, Hoffman AD, Kramer SM, Landis JA, Shumbukuro JM, Oshiso LS. Isolation of lymphocytopathic retroviruses from San Francisco patients with AIDS. Science 1984;225: 840-3.

10 Imrie AA, Kehrer S, Smith GW, Penny R, Cooper DA. Seroimmunology of AIDS retrovirus infection. I. Use of immunofluorescence assays to confirm sera with ELISA reactivity. Pathology 1986;18:438-43.

11 Melbye M, Bayley A, Manuwele JK, et al. Evidence for heterosexual transmission and clinical manifestations of human immunodeficiency virus infection and related conditions in Lusaka, Zambia. Lancet 1986;ii:1113-5.

12 Weber JN, McCreaner A, Berrie E, et al. Factors affecting seropositivity to human $T$ cell lymphotropic virus type III (HTLV-III) or lymphadenopathy associated virus (LAV) and progression of disease in sexual partners of patients with AIDS. Genitourin Med 1986;62:177-80.

13 Kingsley LA, Kaslow R, Rinaldo CR Jr, et al. Risk factors for seroconversion to human immunodeficiency virus among male homosexuals. Lancet 1987; ;:345-9.

14 Harris C, Small CB, Klein RS, et al. Immunodeficiency in female sexual partners of men with the acquired immunodeficiency syndrome. N Engl J Med 1983;308:1181-4.

15 Spira TJ, Des Jarlais DC, Marmor M, et al. Prevalence of antibody to lymphadenopathy-associated virus among drug-detoxification patients in New York. $N$ Engl J Med 1984;311:467-8.

16 Ramsey RB, Palmer EL, McDougal JS, et al. Antibody to lymphadenopathy-associated virus in haemophiliacs with and without AIDS. Lancet 1984;ii:397-8.

17 Redfield RR, Markham PD, Salahuddin SZ, Wright DC, Sarngadharan MG, Gallo RC. Heterosexually acquired HTLVIII/LAV disease (AIDS-related complex and AIDS). Epidemiologic evidence for female-to-male transmission. JAMA 1985;254:2094-6.

18 Melbye M, Biggar RJ, Ebbesen P. Epidemiology-Europe and Africa. In: Ebbesen P, Biggar RJ, Melbye M, eds. AIDS, a basic guide for clinicians. Copenhagen: Munksgaard/Saunders, 1984: 29-42.

19 Quinn TC, Mann JM, Curran JW, Piot P. AIDS in Africa: an epidemiologic paradigm. Science 1986;234:913-1044.

20 Blacker P, Tindall B, Wodak A, Cooper D. Exposure of intravenous drug users to AIDS retrovirus, Sydney 1985. Aust NZ J Med 1986;16:686-90.

21 Moss AR. AIDS and intravenous drug use: the real heterosexual epidemic. Br Med J 1987;294:389-90.

22 Jeffries E, Willoughby B, Boyko WJ, et al. The Vancouver lymphadenopathy-AIDS study: 2 . Seroepidemiology of HTLVIII antibody. Can Med Assoc J 1985;132:1373-7.

23 Conant M, Hardy D, Sernatinger J, Spicer D, Levy JA. Condoms prevent transmission of AIDS-associated retrovirus. JAMA 1986;255:1706.

24 Mann J, Quinn TC, Piot P, et al. Condom use and HIV infection among prostitutes in Zaire. $N$ Engl J Med 1987;316:345. 